\title{
Ethical challenges facing Zimbabwean media in the context of the Internet
}

\author{
Tendai Chari
}

\begin{abstract}
The Internet has fundamentally transformed the practice of journalism in Africa. It has spawned enormous opportunities and challenges for the African media, and Zimbabwe is no exception. Not only has the concept of news changed but also the manner in which it is gathered and disseminated. Journalists no longer feel compelled to adhere to the ethical cannons of their profession owing to certain qualities of the Internet. This paper investigates ethical challenges faced by the Zimbabwean media as a result of the Internet. In particular the paper discusses ethical challenges in the Zimbabwean media that are either directly or indirectly linked to the Internet. The main argument advanced in this paper is that while the Internet has brought about a number of opportunities for the Zimbabwean media, the same technology has been the root of unethical reporting.
\end{abstract}

\section{Introduction}

The Internet or World Wide Web (WWW) has phenomenally transformed the way journalism is practised in Africa in general and in Zimbabwe in particular. It is now easier for journalists to gather news from any corner of the globe and send stories to their newsrooms. Where it used to take months to disseminate news, now it is a matter of clicking a button. Today most publishing houses can post their newspapers on the Internet where they can be accessed by more readers thus bringing value to their advertisers. Notwithstanding these positive aspects of the Internet the euphoria associated with it has tended to marginalise debate on the ethical implications, particularly the ethical dilemmas and challenges which the internet portends. This paper explores the ethical challenges faced by both the mainstream and online media in Zimbabwe.

\section{Conceptual framework}

The term 'ethics' is as controversial as all other moral issues. Scholars hardly agree on one single concept with the consequence that each concept takes on various shades of interpretation. Gordon \& Kittros (1999) define media ethics as a 'field that deals with nearly an endless array of gray areas where issues and appropriate courses of action are not clearly demarcated. In other words, there are no fixed "right answers".'

Sometimes it is hard to clarify the questions. Merrill (1999:2) elaborates on the ethical cobweb scenario in which the mass media are enmeshed when he observes that journalists have to decide 
what is right or the best course of action to take in a context where the practice of journalism has to be done in a hurry. At the core of the practice of journalism are questions such as: what is worth publishing and what is not and which parts of a story should not be published. McDonald and Petheram (1998:4) further elaborate the observation made by Merrill when they note that, although ethical dilemmas confronting the media rest on the individual plank, much of the time they have a potential to move to a more general and broader level, especially when dealing with issues that relate to the wider society.

The absence of universally agreed moral standards makes media ethics such a hotly contested terrain. Journalists operating in different jurisdictions and cultural contexts emphasise different values. For instance, a journalist in the United States of America may place more attention on individual freedom while one in a developing country may feel duty bound to respect the collective interests of the community in which he or she lives.

Moreover, in their day-to-day operations, journalists are forced to make choices between protecting community interests or pandering to the commercial whims of mass media owners. Thus, journalists operating in different cultural contexts appeal to different ethical norms to guide them in order to arrive at the most 'morally upright' decision. Christians (1983:9) identifies five ethical principles which have historically provided guidance on moral decisions. These are:

- Aristotle's Golden Mean: This principle rests on the assumption that virtue lies between two extremes. Thus, a morally upright journalist is neither the one who is a coward nor bashful. Aristotle emphasises moderation for the appropriate actions.

- Emmanuel Kant's Categorical Imperative: “Act on that maximum by which you will to become a universal law". This principle emphasises that "what is right is right and must be done even under the most extreme conditions' (Christians, 1983:11). If, for example, a journalist is convinced that publishing a particular story is the right thing then he or she must go ahead and damn the consequences.

- Mills Principle of Utility: is predicted on the philosophy that man must 'seek greatest happiness for the greatest number'. In other words, what is right is that which pleases the greatest number of people in a nation. Christians observes that this ethical view is widespread in American society which is characterised by hedonism - the perpetual search for pleasure.

- Rawl's Veil of Ignorance: 'Justice emerges when negotiating without social differentiation'. This principle rests on Rawl's principle that fairness is a fundamental tenet of justice. In a sense, justice is viewed as a 'cloistered virtue' which is blind to social status, colour or creed. All people must be treated fairly without fear or favour. Being morally blind means that the media do not treat the powerful in society as sacred cows. All creatures, great and small ought to be subjected to the same moral standards. 
- The Judeo-Christian-Persons as Ends: This "love your neighbour as yourself" principle views all human beings as standing under one moral virtue. Love is viewed as more than a raw principle, stern and unconditional (Christians, 1983:16). The unconditional love due to humanity makes it immoral for anyone to use human beings for the purpose of achieving certain ends. Loving one's neighbour is a practical action that entails helping those who need help such as the weak, the poor, orphans, widows, aliens, the disenfranchised and the downtrodden in society. This principle exhorts media practitioners to use their privilege to highlight the plight of the poor and needy in society.

Although these principles provide useful guidelines on negotiating moral choices, they fall short of capturing other socio-cultural realities. The fact that they originated from Europe during a particular historical epoch, suggests they may be difficult to apply to other contexts such as the developing world or African context. This paper derives inspiration from Francis Kasoma's African ethics (Afriethics) principle which is grounded in African philosophy and culture. Kasoma argues that a 'link can be made between Afriethics and the practice of journalism by Africans based on the premise that journalists serve first and foremost their own society and secondly the world at large' (Kasoma, 1996:104).

Notwithstanding the differences in perspectives regarding the best principle the imperatives for media practitioners to have some kind of guiding moral compass has become more compelling particularly in a globalising world. Democracy can only thrive if information is made available to citizens. As noted by Belsey \& Chadwick (1992:3), the dissemination of information requires the media to act as a catalyst for understanding and social action:

The sort of alternative democratic participation and involvement that is required is impossible without information. Here, then, as people of the world struggle for a worthwhile way of life within a sustainable future, is a role for the media, especially those that can still be called the press, whether they are part of print or broadcast journalism, so long as they follow the traditional role of the press as providers of information.

This paper argues that not only information, but quality, uncontaminated information has the potential to deepen the democratic culture of a nation. It is also argued here that no media is capable of empowering citizens if that media is not rooted in an ethical and moral culture. To that extent the issue of ethics becomes interwoven with questions of democracy and development. Although this paper does not wish to propose a purist approach to ethical journalism it does not subscribe to the elevation of media freedom to pedestal levels while relegating professional ethics to the backburner.

\section{Current research on global media ethics}

The debate on new media and ethics and the one on the search for global media ethics are not mutually exclusive. In fact debate on new media and ethics is an extension of the bigger debate about global media ethics. The debate on global media ethics provides an overarching framework to issues relating to new media and ethics. To that extent this paper will first address issues related to research on global media ethics and then focus on current perspectives relating to new 
media and media ethics. Brislin's contention that 'globalisation has necessitated a "re-evaluation of standards in numerous enterprises including journalism", is worth pondering on.

It is also noted that the question of which ethical principles journalists should subscribe to globally is a vexing one. The debate rages on. At the expense of sounding old fashioned or relativist the point can be made that different societies have different political histories which in turn shape the communication ethics. This is because ethics are embedded in socio-historical experiences and cultural capital of a society. As a result it might appear that different societies may seem to accentuate certain ethical principles while subsuming others.

However, there are certain traceable common denominators of core values which are not only universal but also enduring. In the media ethical principles such as 'objectivity', 'balance', 'impartiality', 'truth-telling' and 'integrity' are celebrated universally notwithstanding the fact that they may be conceived differently. In their book Communication Ethics and Global Change Cooper, Clifford, Plude \& White (1989) note that in many countries consideration of media ethics ask deontological questions to do with moral duties and obligations of the media practitioner. As a result communication practitioners have a hierarchy of loyalties such as social responsibility, truth telling, empowerment role, and other beliefs. Cooper (1989; xxvi) notes that: '...while at one level there are seeming ethical universals among communicators such as commitment to truthful expression, there are also ethical differences among communicators to different national, cultural, political and religious backgrounds.' Thus Cooper sees various levels of universalisms rather than a single universal. In his earlier works Christians advocates for universal ethics but is cautious in the sense that while he advocates for a 'normative foundation of morality' he hastens to say that while such a framework is essential it is not sufficient (Christians, 1989:19). Christians argues (1989:16) that norms are the epicentre of ethical theory that transcends cultures and criticises Anglo-American ethics for lacking clear normative ethics such as 'justice, compassion, reciprocity, stewardship'. He writes (1989:19) that these ethical values are cornerstones of humanity which are not negotiable:

For us to be able to appeal to supreme value of life, to an affirmation of universal human dignity and freedom we cannot do so without accepting norms...that are nonnegotiable...Without norms that are more than objective we cannot finally condemn oppression and dehumanization except on the grounds of personal prejudice or emotional make-up.

Nordenstreng (2004) accentuates social responsibility as the solution for a globally unifying communication ethic. However Rao \& Wasserman (2007:33) have critiqued this proposition citing the historical origins and context of the theory as problematic. They argue that:

The origins of social responsibility are intertwined with western notions of liberal democracy and media professionalism. 
They also note that Nordenstreng \& Christian's 'communitarian' conception of social responsibility is a 'tampered one' suggesting that it cannot be easily universalized.

Rao et al (2007:34) present a critique of Brislin's argument that journalism should focus on empowerment arguing that indigenous theories should not be forced into a framework that purports to be universal when in fact it has been developed in 'Enlightenment Philosophies'. They advocate for a 'post-colonial theory' of communication ethics. We, however, think that the term 'post-colonial' is problematic and needs to be unpacked further. For instance, a question could be posed as to whether post-colonial necessarily means absence of imperial influence. What about the view that in the post colony a more nuanced and subtle, but powerful form of colonialism, continues under the guise of 'globalisation' and the argument that globalisation perpetuates imbalances in power? Notwithstanding, we concur with Rao et al's view that the research for global media ethics must incorporate ethical values such as Ubuntu and Ahimsa.

We note also Christians's article entitled Ubuntu and communication in media ethics (2004) where he revisits his view that media ethics should rest on a normative theory. He identifies Ubuntu as a viable alternative for the individualistic liberal philosophies of the West which view humans as disconnected atoms. Christians argues that unlike western liberal ethical values Ubuntu regards every human being as a fountain of knowledge with something valuable to contribute. For Christians (2004:250) Ubuntu embodies fundamental truth about humanity. We, however, differ on his views that he does not see the necessity of developing professional codes of ethics for media professionals preferring, instead, to work within what he refers to as 'general morality'. We feel that professional ethical codes, although not a panacea, are necessary because they act as cornerstones of a profession. Without them professionals would be like a ship without a radar in night without a star.

We are, however, cognizant of the fact that professional codes should not be cast in stone and that they should be subject to periodic reviews to ensure that they stay in tandem with changing realities. While Ubuntu is a laudable guiding philosophy it is possible to distil from it certain ethical principles which can be codified for the benefit of members of the profession. We feel that ethical principles such as objectivity, balance, impartiality, truth telling, integrity and respect for others would not conflict with the core values of Ubuntu as they tend to appeal to many cultures.

\section{New media and the search for global ethics}

The issue of new media and ethics has attracted considerable response - particularly in Western countries where the Internet is widely accessible (Berkman \& Shumway, 2003; Arant 2000; Lasica, 1997). There is a bourgeoning body of literature on the subject; particularly journals such as the American Journal Review (AJR) and other publications on the Internet. In their book Digital dilemmas: ethical issues for online media professionals Berkman et al locate the subject of new media ethics within the broader concerns about media ethics in general and then focus on ethical dilemmas faced by the new media. 
Through the use of case studies, historical summaries and illustrations they discuss ethical dilemmas and challenges such as sourcing, intellectual property rights and conflict of interest. Berkman et al note that new media practitioners are afraid of being constrained by old rules of traditional media such as the necessity of verifying and confirming facts before going to print.

Ethical challenges and dilemmas highlighted by Berkman et al here help illuminate ethical challenges faced by the media in Zimbabwe. Arant (2000), on the other hand, utilises the survey method complemented by a literature review that provides insights on practical challenges faced by online journalists. He identifies main challenges faced by online media practitioners as copyright and privacy issues, attribution problems and the blurring relationship between editorial and advertising content. Arant notes that the gate keeping role of editors has been subverted by the internet resulting in the quality of media products being at stake. The importance of Arant's work lies in that it is a wealthy source of data gathered from the field. We concur with his argument that new media need to update ethical protocols so that they take into account realities of the new medium. In this paper we wish to extend the frontiers of Arant's argument by suggesting that the updating of ethical codes for new media should not result in discarding the core values that have guided traditional media for centuries. We are in favour of an incremental approach to ethics whereby the old wisdom that has guided the profession should be complemented (but not necessarily replaced) by new thinking.

To that extent we feel that time tested ethical principles such as objectivity, balance, truth-telling, impartiality, right of reply, integrity and respect for others should be emphasised instead of being relegated to the back stage. In this regard we share Bradely's view that although new forms of journalism require new approaches to ethics many current ethical values remain and others will emerge (Bradely, 2001). Bradely's concern about the need to restore credibility in online publications is laudable. She argues that one of the reasons for the waning credibility of online news publications is lack of training and the obsession with speed. Hyland (1995) argues that online journalists, at the mercy of instant publication, take less time to check their stories thereby undermining journalism. Bradely (2001:6) observes that the internet has brought about a multiplicity of senders and receivers thus dealing a blow to editorial agenda-setting. We agree with Bradely when he says there is a need to adhere to conventional ethics in new media.

We wish to elaborate through illustrations and selected cases how unethical practices can undermine the credibility of journalism in general and Internet journalism in particular. We wish to argue that the restoration of the credibility of new media will enhance the informational role of these media. We go along with Lush's view that: 'For the media to demand accountability it too must be accountable, just as in the same vein, for the media to be pluralistic it must reflect the diversity of the societies in which it operates (cited by Nyamnjoh, 2005:81). We argue further that accountability and pluralism of views in these media are not possible if these media abandon ethical values which have guided traditional media since time immemorial. To that extent we concur with Lasica's argument that technology does not make ethics old fashioned hence traditional journalism ethics should be preserved in the new media (Lasica, 1997). The need to embrace enduring core values of the past is a persuasive line of argument. Lasica (1997:2) identifies these core values as integrity, balance, accuracy, respect for others and fairness. 
It is noted here that the large body of literature on new media and ethics is based on Western case studies and practices. Little attention has been given to new media ethics in the South, Africa in particular. This paper attempts to provoke debate on ethical dilemmas and challenges faced by the media in Africa in the context of a technological revolution epitomised by the Internet.

Our view is that while ethical challenges and dilemmas faced by media practitioners are generally the same the actual experiences and practices may differ. Differences in socio-cultural and political contexts may give rise to different media practices. This paper brings in the African experience and perspective which is largely missing in existing literature. The next section of the paper gives an overview of the media situation in Zimbabwe so as to provide the broader context of the paper.

\section{The media situation in Zimbabwe}

At independence in 1980 Zimbabwe inherited a fairly diversified media landscape characterised by a vibrant state owned media and a blossoming private press reflective of the existing economy which was dominated by private white capital (Chari, 2006). At the onset of independence the ruling Zanu PF government acquired the Rhodesia Printing and Publishers from the South African based Argus Newspaper Group using a grant provided by the Nigerian government, thus making it the major shareholder in the newly formed Zimbabwe Newspapers Group (Ltd) (1980) - publishers of dailies The Herald and The Chronicle. Zimpapers and the state owned news agency, Inter-Africa News Agency (ZIANA), the Zimbabwe Information Service (ZIS), and the Community Newspaper Group (CNG) fell under a newly created trust, the Zimbabwe Mass Media Trust (ZMMT) while the state broadcaster, the Zimbabwe Broadcasting Corporation (ZBC), which has remained the only broadcaster to date, fell directly under the Ministry of Information and Telecommunications. The Ministry has on many occasions been renamed. It became a Department in the president's office after the 2000 parliamentary elections but reverted to a fully fledged ministry in 2005 and is currently called the Ministry of Media, Information and Publicity.

The absence of a comprehensive indigenisation plan for the media allowed the private sector to grow. Thus the number of private publications increased and there was existence of relative press freedom (Saunders, 1991).

Although the private press was very critical of the new black majority government there were no specific media controls or legislation. The only threat to media freedom was the existence of colonial relics such as the Law and Order Maintenance Act (1965) which was justified on account of state security threats from the apartheid regime in South Africa, the civil war in Matebeleland (after independence some dissident elements linked with the major opposition party ZAPU refused to join the new integrated army and engaged in military insurgence killing 
civilians in parts of Midlands and Matebeleland provinces) and the threats from Renamo bandits in Mozambique. This attracted a heavy handed military operation dubbed 'Gukururahundi' (clean up trash) in which thousands of civilians died.

The only form of registration which existed was through the Post Office and this was more of a formality.

Thus, in the absence of a codified media policy the press flourished. There was no collective code of ethics for either professionals or within media houses.

The second decade of independence (1990-1999) is remembered as the 'golden age' of the press in the country as it saw phenomenal growth in the press: privately owned publications included the investigative monthly Horizon (1991), The Daily Gazette (1992), The Sunday Gazette (1993) (These two Gazettes did not last long due to financial reasons and folded in 1994), The Zimbabwe Independent (1996), The Standard (1997), The Zimbabwe Mirror (1997) (later became The Sunday Mirror) and The Daily News (1999). The launch of The Daily News by the Associated Newspapers of Zimbabwe (ANZ) completely changed the face of the Zimbabwean media landscape.

ANZ launched newspapers in almost every province in the country thus challenging government dominance in the information business (Most of them did not last over a year and collapsed due to viability problems). The Daily News had a greater impact on Zimbabwean society because it was published five days a week (the paper started publishing six days a week from December 2000) and also because it stood on a more solid financial base compared to previous newspapers (Waldahl, 2004). As of 2001 The Daily News's readership grew phenomenally and its circulation surpassed that of the state run The Herald (The Daily News reached a readership of 100000 compared to The Herald's 90 000) (Makore cited in Waldahl, 2004:37). Prior to the Formation of The Daily News, state dailies, namely The Herald and The Chronicle had been the only daily newspapers in the country. The formation of the Daily News coincided with the formation of the Movement for Democratic Change (MDC), a new political party backed by a coalition of civil society organisations. Within the context of rising dissent within the populace, occasioned by deteriorating economic conditions, The Daily News became a strategic conduit for venting popular discontent. Its militant approach meant that a collision course with state under siege was inevitable.

In an attempt to tame the militant media government promulgated stringent laws such as the Broadcasting Services Act in 2001; Access to Information and Protection of Privacy Act (AIPPA) in 2002 and the Public Order and Security Act (POSA) in 2002. It is important to note 
that POSA is not a media law per-se but a security law which precursor was the Law and Maintenance Order Act (1965). The law was drafted in the late 1990s ostensibly to deal with security issues associated with rising dissent within the country such as demonstrations, strikes etc. However the Act has a few sections that affect the operations of mass media.

The Daily News and its sister publication The Daily News on Sunday refused to register with the state appointed Media and Information Commission (MIC) as per requirements of AIPPA and was closed in September 2003, resulting in several workers, including journalists, being displaced. Due to the shrinking of media space and scarcity of job opportunities in the media following the closure of The Daily News and its sister publication The Daily News on Sunday,

The Business and Weekly Tribune (closed in June 2004 after failing to comply with sections 67 and 71 of AIPPA resulting in the cancellation of their licence), and The Weekly Times (closed February 2005 after failing to notify the Media and Information Commission (MIC) about changes in their editorial content and thrust) and retrenchments at the state owned and sole broadcaster the Zimbabwe Broadcasting Corporation (ZBC) a good number of journalists emigrated to the United Kingdom, Canada, South Africa, Botswana and various European countries.

The majority of former broadcasters are now working for 'pirate' radio stations such as SW Radio Africa in London, Studio \& which is hosted by the Voice of America (VOA) in Washington, Voice of The People (VOP), while former Daily News journalists and others affected by the closures have started online publications such as NewZimbabwe.com, ZWNews.com, Zimbabwejournalists.com, ZimOnline.com and ZimDaily.com, The Zimbabwe Times.com among others.

The Committee to Protect Journalists says Zimbabwe has the highest number of journalists (estimated to be about 90) living outside their country making it 'one of the largest groups of exiled journalists in the world' (Nyakunu, 2005). The closure of two other privately owned newspapers, The Daily Mirror and The Sunday Mirror, in early March 2007 due to financial problems has further shrunk the media space in the country both in terms of employment opportunities and the availability of voices that are alternative to the government. As a result the only privately owned newspapers are The Financial Gazette, The Zimbabwe Independent, The Standard (The Zimbabwe Independent and The Standard are owned by Zimbabwean and South African based business man Trevor Ncube who is also the owner of the South African Mail and Guardian), The Zimbabwean, which is published in London, and a few regional newspapers. 
That leaves the government claiming the lion's share of the media space, owning the vast newspaper empire under Zimpapers namely The Herald and The Chronicle which are both dailies, The Manica Post, The Sunday News, Kwayedza, and Umthunywa. The Sunday News is a regional weekly published in Zimbabwe's second largest city Bulawayo, while The Manica Post, also weekly, is published in the eastern border town of Mutare, in Manicaland province. Kwayedza and Umthunywa are vernacular - Shona and Ndebele words for 'dawn' (Shona and Ndebele are the main and second major vernacular languages spoken in Zimbabwe respectively). Governments also owns the only broadcaster in the country the Zimbabwe Broadcasting Corporation (ZBC) which has got five radio stations and one television channel. In addition government owns the financially struggling New Ziana, a multimedia news organisation and the Community Publishing Group which runs newspapers in the country's ten provinces. New Ziana was supposed to operate a television station and a number of radio stations but has not been able to do so because of financial constraints. On the other hand the Community Newspaper Group's provincial newspapers are almost extinct. Most of them have not been able to publish regularly and their circulation figures have dropped drastically to become insignificant.

In terms of reporting, the media in Zimbabwe is polarised along political lines. Both the privately owned and state owned media hold entrenched positions on almost every issue, be it sport, entertainment, business or politics. The state media is unapologetic in its support for the ruling Zanu PF government while the private press seems to have signed a pact with the opposition to 'hear no evil', 'speak no evil' and 'see no evil' regarding its affairs. After the closure of The Daily Mirror and The Sunday Mirror and the Tribune (three newspapers which tended to walk a middle of the road line editorially, resulting in them being labeled 'middle of the road' newspapers) there is no third reference point in terms of news since the two media camps hold extreme views. As a result news reporting has become too predictable and readers are forced to read all the newspapers available in order to get the truth. Newspaper columnist Pathisa Nyathi's (MMPZ, 2002:87) observation succinctly illustrates the extent of the situation:

The polarisation in our society today is bets depicted in the press. Basically the press is either pro-government or anti-government. Sometimes objectivity is sacrificed on the altar of expediency in order to be true to their chosen position...If you buy newspapers from one divide, you will get half the story.

Online newspapers and websites that focus on Zimbabwe that should have provided a true picture are also embroiled in polarisation, if not worse. They are domiciled abroad and because of this they are practically detached from reality on the ground which makes it difficult to be balanced and objective. As Lush \& Kupe (2005:10) state: 
The further you are from the story, the more difficult it is to be objective in tune with the often complex dynamics of a story unfolding thousands of kilometres away...Distance alone makes it extremely difficult for journalists outside the country to fill the information void created by the state's propaganda machinery...

\section{Online publications/websites}

A common feature of online publications is their focus on Zimbabwean news and a latent proopposition slant and the fact that their ownership is traceable to former employees of the Daily News. Their focus on Zimbabwe resonates with their editorial slants and their mottos. For instance, The NewZimbabwe.com's motto is 'The biggest name in Zimbabwean news' while that of ZimOnline is 'Zimbabwe's Independent News Agency'. ZWNews.com's motto is 'The World's leading website on Zimbabwe'.

Almost all of these publications have a traceable link with The Daily News in terms of personnel. Nyarota (2008) sheds light on ownership of some of the websites when he observes that:

Out of the ashes of then Daily News emerged Wilf Mbanga's The Zimbabwean, Geoffrey Nyarota's The Zimbabweantimes.com. Abel Mutsakani's Zimonline.com, Mduduzi Mathuthu's Newzimbabwe.com, Sandra Nyaira's Zimbabwejournalists.com and Makusha Mugabe's Changezimbabwe.com (Nyarota, 2008).

The Zimbabwean is more of a 'husband and wife affair' with Wilf Mbanga as the editor, and his wife Trish as 'chief sub editor' (Genevieve, 2005). Mbanga is former editor of state-run news agency Ziana, former executive of Associated Newspapers Zimbabwe (ANZ), publishers of the defunct Daily News.

Some scholars have lauded these publications for acting as credible 'alternative forms of democratic participation' thus failing to interrogate their ethical performance (Moyo, 2007).

Within the polarised framework of Zimbabwean politics, it is tempting to adopt a 'human rights' humanism approach that is bereft of moral content where the state controlled media is viewed the 'Devil' and the pro-opposition media as the 'Angel'. Such an approach thus fails to critique the complexities that have characterised the Zimbabwean media terrain since 1999.

Celebration of pluralism should not blind us to the extent of forgetting the social responsibility of the media which is itself the bedrock of empowerment.

As noted by Musa (1996) and Kasoma (1996), lack of commitment to professional ethics by the media among other constraints may result in the media disempowering rather than empowering.

Kasoma (1996:95) argues that: 
in a world in which the information superhighway has made journalists practice their profession in a hurry as they strive to satisfy the world's craving for more and quicker news and other information, the humanness of journalism has increasingly been giving way to the expedience of cut-throat financial competition.

In light of the above views, there is a need to critically examine the ethical performance of both the traditional and online media rather than uncritically harping on their 'democratising' function. To that end, questions such as how the Internet has transformed journalistic practices and the attendant ethical challenges confronting both traditional and online publications are legitimate issues that this paper seeks to address.

\section{The Internet in Africa}

Although the internet is still a pipe dream for the majority of Africans (about 70\%) who reside in rural areas, its use within the continent is growing fast. Technology has been used to achieve milestones in the fields of health, tourism, trade and commerce, education and the media (Kenny \& Hawkins, 2000; Roycroft \&Anantho, 2003). Latest studies put the number of Internet users in Africa at 51,022,400 (representing 14.3 percent of the total continental population of 955,206,348), (InternetWorldStats-www.internetworldstats.com. 2008-03). This figure constitutes about 3.6 percent of world Internet users and Internet penetration rate for the continent is put at 5.3 percent compared to the world average at 21.1 percent (InternetWorldStats, 2008-03).

The picture is, however, not so gloomy for the continent considering in particular the fact that Internet use has witnessed phenomenal growth between 2000 and 2008, thus having achieved a growth rate of 1,030,2 percent between that period. This is far more than the world average growth of 280.6 percent between the same period (InternetWorldStats, 2008-03). The ten top African countries in terms of Internet use have been identified as: Nigeria (10 m users), Egypt, $(8.6 \mathrm{~m})$, Morocco, South Africa, (5.1m), Algeria, (3.5m), Kenya, (3.0m), Uganda, (2.0 m), Tunisia, $(1.7 \mathrm{~m})$, Sudan $(1.5 \mathrm{~m})$ and Zimbabwe (1.4 m) (Internetworldstats.com).

Non-Governmental Organisations (NGOs), academic and research institutions, industrial and commercial sectors, governments and the media have been identified as those who use the Internet the most in Africa (Chisenga, 1999; Jensen, 2000; Alden, 2004). This means that the Internet is still an elite and urban phenomenon, as the majority of people who live in the rural areas do not have access to it. Major stumbling blocks in the diffusion and development of the Internet in Africa include absence of requisite infrastructure (telephones, computers and electricity), lack of training, low incomes, high costs of connectivity, illiteracy, costs of and lack of commitment by governments who may not appreciate the advantages of connecting to the Internet (Jensen, 2000; Alden, 2004; Kenny \& Hawkins 2008).

Andres, Cuberes, Diouf, \& Serebrisky (2008:13), who conducted a cross country analysis of the diffusion of the Internet, note that income levels and telecommunication infrastructure have significant positive effects on Internet use. Roycroft \& Anantho (2003) accentuate economic factors as key to Internet and observe that there are no 'High-Income' countries in Africa and 33 
countries are classified as 'Least Developed Countries' leaving only Gabon, Mauritius Seychelles and South Africa in the 'Middle - Income' group. This scenario leaves Africa in a disadvantaged position in so far as the development of the Internet is concerned given the high levels of poverty and the absence of telecommunication infrastructure. The picture is not very encouraging taking into account the International Telecommunication's observation in 2005 that Africa has an average of 3 fixed telephone lines for 100 people compared to say the Americas with an average of 34 fixed telephones per 100 people (ITU, 2005). It is also noted that of the 26 million fixed telephone lines that Africa has over 75 percent of them are in just six of the 55 African countries. This means that in Africa there are various levels of talking about the digital divide which makes the development of the internet an uphill task.

\section{The Internet in Zimbabwe}

Although Zimbabwe was considered a latecomer in jumping onto the information superhighway band wagon, significant strides have been made in Internet connectivity. According to internetwoldstats.com (March, 2008) the number of Internet users in Zimbabwe stands at 1.351,000: which represents about 10.9 percent of the population. The Internet penetration rate, which is defined as the number of Internet users over the total population in percentage, is estimated to be 9.8 percent and the number of broadband subscribers at 10,200 while the broadband penetration rate stands at 0,1 percent (Internetworldstats.com, 2008). In spite of the economic crisis which has gripped the country since 2000 the number of Internet users appears to be growing steadily over the years.

The number of Internet Service Providers (IPS) also continues to grow: from six in 2003 to 27 in 2004. The growth in the IPS sector is reflective of the growing demand for internet service by the business community and the general public. In 2004 Harare alone, the capital city had about 30 internet cafes and in 2008 there are estimated to be double that number (Interview with Chirovamavi 2009). A number of colleges in Harare and various towns in the country offer training in computers - thus exposing the youth to computers. Government also has a programme whereby it distributes computers to schools and in the country thus promoting computer literacy which is key in Internet use. The desire by these young people to access educational and entertainment information has also contributed to the growth of the Internet. The need to stay in touch with relatives who went into the Diaspora to seek economic fortunes because of the economic crisis also appears to be promoting widespread use of the Internet in the country. According to the DFID, Foreign Commonwealth Office (2008) it is estimated that about three million Zimbabweans are staying outside the country mostly to seek a better life because of the economic crisis (these figures differ from source to source).

For local media houses the Internet is almost like a gold mine. It has become a major source of breaking news and other events taking place in distant places. All news organisations in the country use copy from global news organisations such as Reuters, Sky News, etc. Global news organisations do not only have a sound technological 'backbone' but also command the financial clout that enables them to spread their tentacles across the length and breadth of the globe. They 
can afford to have stringers or correspondents almost in every country or region thus enabling them to have first hand accounts of events.

In spite of the strides made in Internet use in Zimbabwe several challenges remain, including the prevailing economic crisis which is characterised by a hyperinflation environment. Connectivity costs are now beyond the reach of many who are struggling to provide basic commodities for their families. Personal computers are now beyond the reach of many and the telephone infrastructure is deteriorating due to lack of both maintenance and foreign currency. The costs of accessing the Internet are soaring and many find it difficult to afford. Internet Cafes charge anything between US\$0.50 to US\$1,00 (at the time of writing the exchange rate was US\$ 1 to Z\$ 3 billion) for 30 minutes, an amount which beyond the reach of many. Thus, in spite of the enthusiasm associated with the Internet, there are numerous challenges threatening its diffusion.

\section{Methodology}

Convenient sampling or purposive method was used to identify news articles published between 1999 and 2008. Two main criteria were used in this regard. The first centred around those news articles that had generated controversy or where allegations of violation of law and ethics had been made about a reporter or publication. For print media publication the violation of misconduct should have been acknowledged by the publication or journalists concerned possibly resulting in a retraction (in the case of publication) or disciplinary action being taken against the offending journalist.

The story would then be assessed to ascertain whether it violated universal journalistic ethics such as fairness, balance, impartiality and objectivity which lie at the core of the journalism profession. Berkman \& Shumway (2003) note that many journalistic ethical codes around the world place high premium general ethical principles on issues such as: 'informing the public'; 'providing a fair and comprehensive account of events and issues'; 'seeking truth'; 'unbiased reporting'; 'impartiality'; 'the need to identify sources' and 'the need to avoid conflict of interest'.

As has been noted by Gall, Borg \& Gall (1996) in convenient sampling subjects are selected according to the specific characteristics that the researcher 'cares about and subjects can come from any number of sources'. Thus besides the controversial nature of the news articles and the allegations of unethical conduct articles were selected because of their accessibility and availability.

The sampling method was however justified on account of the fact that unethical conduct in the journalism profession is largely committed in very secretive circumstances to the extent that methods of data collection such as interviews and observation would not yield many results. In the circumstances it would be difficult to quantify ethical violations. 
At the same time the haphazard, non-random and unstructured nature of convenient sampling makes this method vulnerable to bias because the sample is chosen on the basis of expediency. Be that as it may the researcher finds merit in Gall et al's (1996:228) argument that:

researchers often need to select a convenience sample or face the possibility that they will be unable to do the study. Although a sample selected randomly from a population is more desirable, it is usually better to do a study with a convenience sample than not to do the study at all - assuming, of course, that the sample suits the purpose of the study.

Fink (2003) also notes that convenient sampling is quick and cheap. In light of these limitations the researcher also reviewed some bourgeoning literature in scholarly and newspaper articles relating to the ethical conduct of Zimbabwean journalists as an attempt to ameliorate the limitations of the sampling method used.

\section{Findings and analysis}

This section discusses findings relating to ethical challenges faced by both the mainstream newspapers and online media in Zimbabwe in the context of the Internet. Focus is largely on the press and online publications or websites run by Zimbabweans in the Diaspora. The last section discusses implications of these findings and an attempt is made to chart the way forward.

\section{Ethical challenges}

In a fast globalising world where the news sources can be too busy to entertain telephone calls, the Internet comes in handy. Letlhoge (2005:41) notes that the internet enables news organisations to update their stories regularly thereby enhancing the quality of their media products. Letlhoge (2005:41) notes that the quality of news is linked to its timeliness. The quality of news is also greatly improved through sourcing of alternative voices on a topic thus ensuring multiple perspectives. Mabweazara (2005:11) notes that there is a common assumption that new communication technologies including the Internet are capable of raising the efficacy of practice in many sectors of the economy, journalism included.

However, belying the numerous opportunities brought about by the Internet is a plethora of ethical minefields associated with the medium, particularly in the conduct of journalism in Zimbabwe.

\section{Factual inaccuracies/errors and fabrications}

The mainstream press and online media in Zimbabwe are becoming more prone to factual errors and fabrications than before. The desire to 'outwit' competitors and the obsession with timeliness means that journalists are less bothered about getting the facts right. As the practice of journalism gets into the 'supersonic mode' the eye of the reporter is fixed on 'scooping' rather than on ensuring that facts are correct. The Internet has promoted cut-throat competition in the news gathering business in the sense that mainstream publications are not just competing amongst themselves but also with Internet based publications with more scope to publish sensational stories because they fall outside the purview of the new stringent laws. The fear of 
losing a scoop brings so much pressure that publications find it difficult to wait until all the facts have been verified.

A case in point is where the privately owned Daily News published a story on 2002-04-23 claiming that Brandina Tadyanemhandu, from Magunje, in the Mashonaland West Province, had been beheaded by ruling ZANU (PF) supporters in front of her two daughters. The story was found to be false and the Daily News retracted it and apologised to the ruling party. In its apology, The Daily News wrote:

Notwithstanding that, until Edna Tadyanemhandu's grave is located and positively identified, we are left with no option but to tender our most sincere apologies to those whose character we were led to impugn. We must apologise to our readers among whom much alarm and despondency was caused by the report in question. Above all, we tender our most profound apologies to ZANU (PF), whose image was tarnished by the report in question (The Daily News, 2002-04-27:1).

Although The Daily News retracted the story other publications that had taken the story from The Daily News web pages did not. For instance, The Guardian (UK) correspondent in Zimbabwe, Andrew Meldrum took the story from The Daily News without verifying it and was published in the newspaper's 24 ${ }^{\text {th }}$ April 2002 edition (Chari, 2007).

It could be argued that the millions of readers who may have read the story believed it, given the violence which was taking place in the country at that time. The Internet thus made the propagation of falsehoods to a wider audience and that has potentially damaging consequences to the image of a country.

Meldrum could not have been able to send so swiftly a story that had not been verified. The real danger associated with such stories is that they may result in readers losing confidence in the media thus resorting to other 'credible sources of information'. It is possible that after the publication of the retraction of this story readers of The Daily News could have felt shortchanged somehow and the circulation of the newspaper could have been negatively affected.

It is, however, worth noting that factual inaccuracies are of two types. There are those that are inadvertent but encouraged by the dictates of time and pressure of time, what I would call the 'scoop phobia' where an inaccuracy results from the fear of losing a story to a competitor. The second category of factual errors is deliberate fabrications made possible by the 'anonymity of the Internet'. In such a case, a journalist knowingly and deliberately fabricates a story and sends it via email to a publication outside the country in the false comfort that no one will ever know. An example is a case involving former Zimbabwe Union Journalists (ZUJ) Secretary General, Basildon Peta, who wrote a false story for the Independent (UK) claiming that he had been arrested and detained in a police cell overnight. The story, headlined 'My ordeal as Mugabe prisoner', appeared in a February 2002 edition of the newspaper but was found to be false (Chari, 2007:45). Peta had written a different version for his newspaper, The Financial Gazette, where 
he was Special Projects Editor. After the discovery of his lie Peta left the country for South Africa where he continues to work as a reporter for a local newspaper.

The anonymity of the Internet makes it difficult to gauge the magnitude of this practice but there is strong belief even among media practitioners that this unethical practice is widespread and is on the rise and that it cuts across the media divide.

In 2002, a number of journalists working for the State run daily, The Herald, were dismissed for allegedly 'moonlighting' for pirate radio stations based in the United Kingdom as well as British online publications based outside the country. There has been speculation that the perceived decline in journalistic standards in the country is due to the fact that journalists are in the habit of producing two versions of a story, one for their publication and another, usually the better one, for an outside publication which pays more money.

It is worth noting, particularly in the context of the economic crisis, that there is a convergence of opinion by those both inside and outside the profession that journalistic standards in the country are deteriorating.

Tsvangirai Mukwazhi, an experienced photo-journalist, points out gross inaccuracies in a story published by ZimOnline.com (2007-03-14). The story, headlined 'EYEWITNESS ACCOUNT: The MDC's courtroom unity and Mugabe's Dogs of War' claimed that a faction leader of the opposition Movement for Democratic Change, Professor Aurthur Mutambara, had been 'assaulted' (although not seriously) by police during opposition protests marches in March 2007. Mukwazhi (2007):

I wish to bring to the public attention certain incorrect information which was contained in a ZimOnline.com story...giving eyewitness account of a particular police officer based at Machipisa Police Station who witnessed the brutal assault of MDC officials and supporters. I spent Sunday and Monday night in the same cell with him; he was never assaulted, as alleged by the Machipisa police officer quoted in the story. He was actually asking us about how people had been beaten. Our two cell-mates...asked Mutambara how come he had not been assaulted.

Instructive to note here is that the author of the story purports to have first hand account of what he is writing about. The problem is that the issue is not what proportion of the story has been found to be untrue but rather the perception that a story containing gross inaccuracies has found its way onto the page which, in turn, creates scepticism among newspaper readers. Readers are likely to take any future stories in such a publication with a pinch of salt.

City Press (SA) news editor and Zimbabwean journalist Japhet Ncube (2007) chastises his Zimbabwean colleagues for impartial, unbalanced reporting, fabrication of stories and 'double standards'. He complains that:

Ethics of this loved craft have been massacred by some among us because we have, wittingly or unwittingly, swallowed the political look and this time we sing for a different 
master. We are no better than our colleagues at the The Herald and Sunday Mail, ${ }^{1}$ who have to get used to naked propaganda.

He adds: 'Finding a Zimbabwean journalist whose writing is impartial is like finding a virgin in Hillbrow $^{2}$ and that [is] very worrying for me.'

Coming from someone with an insider's perspective this statement is as revealing as much as it is instructive. The sentiment resonates with calls for the urgent restoration of an ethical culture in the Zimbabwean media.

It is also worth noting that the problem of factual errors and fabrications gets more acute in online publications. There is a general belief that online publications are more prone to factual errors than the mainstream publications. The major reasons cited for this are:

- Immediacy of the Internet. The Internet is a medium designed for speed and the content turnaround is higher in online publications than mainstream media. Mann (1998) cited by Arant (2000) notes that: 'In a medium built for speed, should the old methods of factchecking remain or can short-cuts be allowed and if so how can an organisation possibly regulate them to avoid costly errors?'Arant (2000) notes that the environment in which journalists operate is in a 'constant state of flux'.

- Shortage of staff. Most online journalists operate with a skeleton staff (referred to as 'bare bones staffs' by Arant. Fitzgerald (1997) cited by Arant notes that a typical online publication in the United States has at best four employees (Arant, 2000). Given the economic constraints of online publications the figure could be much lower. ${ }^{3}$ Arant notes that the creation of short-staffed corporate newsrooms has resulted in a situation where the bottom line takes precedence at the expense of responsibility. The few overworked members of staff have too much to post on the website and yet they have got too little time to do that. As a result there are numerous errors which lead to the loss of credibility.

- Fragmentation of the audience. The Internet has resulted in a situation where the audience for news has been segmented, resulting in cut-throat competition. There is now

\footnotetext{
${ }^{1}$ The Herald and Sunday Mail, owned by the state run company Zimpapers have come under serious attack since 2000 for what pro-opposition critics view as unmitigated biased reporting.

${ }^{2}$ Hillbrow is a crime ridden and according to some morally debased suburb in Johannesburg, the commercial capital of the Republic of South Africa.

${ }^{3}$ It is not possible to tell the staff levels of these online publications given the clandestine manner in which they operate. The majority of them tend to be identified with a single personality who is usually the founder. Most of these publications rely on stringers for their news
} 
greater need for online publication to be the first with news - particularly breaking news and scandals (Online Newshour, 1998 cited by Arant, 2000). Online Newshour notes that 'the crushing demand for fresh news items to fill up airtime twenty-four hours a day making accuracy and balanced reporting more difficult to achieve on a constant basis (Arant, 2000). The pressure to become the first with the news was quite noticeable in Zimbabwean online publications during the harmonised parliamentary, presidential and municipal elections held on the 29 March, 2008 with resulting disastrous ethical consequences. As websites jostled to be the first with the news, they became hostage to the rumour mill with Newzimbabwe.com and other websites reporting that Vice-President Joyce Mujuru had been beaten by an MDC-Tsvangirai candidate while Zanu (PF) political Commissar Elliot Manyika was reported to have lost his seat and that he shot and killed an MDC supporter' (Zimonline.com). These reports were later found to be untrue.

Different websites published conflicting sets of the presidential and parliamentary results with one website inaccurately representing presidential results by claiming that opposition MDC leader Morgan Tsvangirai had received 50.3 percent of the vote, Zanu PF's Robert Mugabe 42 percent and independent candidate Simba Makoni 6.8 percent. House of Assembly election results were also inaccurately represented: MDC (99 seats); Zanu PF (95 seats); and MDC Mutambara faction and independents (12 seats) (Independent Election Results Centre, http://www.zimelectionresults.com). The situation was further exacerbated by the delay in the publication of the results by the Zimbabwe Electoral Commission (ZEC), the body mandated with the running of the elections. These figures differ from the official ones released by the Zimbabwe Electoral Supervisory Commission (ZEC).

- Lack of correspondents. Most online publications do not have full-time correspondents on the ground to monitor what is happening. They are not accredited with the Media and Information Commission (MIC) ${ }^{4}$ and most writers for these online publications use pseudonyms hence it is difficult to tell who they are. Their hidden identity also makes it difficult to tell whether their anonymous sources are real or fabricated. There is a tendency among these publications to rely on informal sources such as acquaintances or relatives and friends working for different newspapers. Sometimes these informal sources are far from reliable. A case in point is the publication by Zimonline.com in 2005 of a story alleging that the three journalists working for foreign news organisations, Brian Latham, Angus Shaw and Jaan Raath, had been arrested by the Zimbabwean government

\footnotetext{
${ }^{4}$ The Media and Information Commission is the board mandated to oversee the accreditation of mass media houses and journalists in the country. Most of the names of the writers that appear on these websites are not on the MIC register. The MIC is currently being transformed into the Zimbabwe Media Council after an amendment of the law (AIPPA) which was agreed during the Zanu PF-MDC talks in 2007.
} 
police for allegedly practising without being registered by the Media and Information Commission (MIC). The story was found to be false and Zimonline (March, 2005) retracted it and apologised stating that:

It has been brought to our attention that Ms Mtetwa, who acts for the trio, that they were never charged or detained by the police. The police only visited the journalists offices on Monday and questioned them about their registration status and some of the communications equipment they use at their offices...We apologise to Ms Mtetwa for attributing wrong information obtained from one of our sources to her. We apologise to the police, our colleagues, Shaw, Raath and Latham for the inconveniences our incorrect story obviously caused. Disciplinary action is being taken against the correspondent who filed the story.

Given the anonymity of the Internet, it is difficult to tell which of their sources are authentic and which ones are not.

- Partisanship. The polarised political environment in Zimbabwe has resulted in both government and the opposition having entrenched positions on almost every issue, be it politics, economics, or sport. Pro-opposition media are prepared to go to any lengths to try and tarnish the government of President Robert Mugabe knowing full well that international opinion is in their favour. Thus, it is easy to fabricate a story where the government is involved without having questions being asked about its veracity.

The government media on the other hand does not need to be bribed to fabricate lies about the opposition in the comfort that their legion of readers will believe them.

Online publications appear to specialise in stories that rubbish President Mugabe and his government even if those stories cannot be substantiated. Moyo (2007:91) notes in relation to these websites:

Mugabe himself has been pronounced dead or severely ill on some of these news websites, only to appear 'alive and kicking' on national television the next day to disprove his 'prophets of doom'. A recent report on Newzimbabwe.com suggesting that Mugabe travelled to Malaysia in a bid 'to save his marriage' for example has been mainly 'speculative'. It is worth noting that online publications have latched onto any story or rumour that puts government and the president regardless of its authenticity.

\section{Plagiarism}

One ethical challenge confronting the Zimbabwean media today is plagiarism. The word plagiarism comes from 'plagiarus' which is the Latin word 'kidnapper' or an act of stealing from others their thoughts or their writings and claiming them for one's own (Watson \& Hill, 1994:134). Brian Martin (1984) notes that there are many varieties and degrees of plagiarism. 
The main ones are 'direct stealing, without significant alteration, of others' work', or 'word for word plagiarism', which is the most obvious form of plagiarism, 'paraphrasing from unacknowledged sources' and 'unconscious paraphrasing' from a source without proper acknowledgement (Martin, 1984).

The anonymity of the Internet makes it difficult to gauge the magnitude of the problem of plagiarism in Zimbabwe. A close analysis of the newspapers reveals a striking identity of stories in different publications which might suggest the prevalence of plagiarism. Similarity in headlines, phrases, introductions and conclusions of stories are common.

An example is seen in the story about the death of Ngugi Wamirii - the Kenyan born and Zimbabwean writer who died in May 2008. Several print and online publications that cornered the story had identical sentences, headlines and paragraphs suggesting that there was plagiarism. The Zimbabwe Metro (2008-05-03), News24 (SA) (2008-05-04) and the Sunday Nation, Nairobi (2008-05-03) all contained the following verbatim:

Mirii went into self-imposed exile in the Southern African nation in the 1980s, following a crack down on political dissent by the President Arap Moi.

And:

he left Kenya along with playwright Ngugi wa Thiongo now based in the US after they co-authored a play called Ngaahika Ndeenda or I will marry when I want which poked funny at the ruling elite.

It is important to note that in both The Metro.com and News24 reports 'Want' in 'I will marry when I Want' was misspelt as 'Wont'. The possible explanation for this similarity is plagiarism from source by both publications.

In the mainstream media, there have been a number of cases of plagiarism that have been reported over the past few years. Notable is the one involving Phyllis Kachere, a line editor with the State run weekly, The Sunday Mail, who in 2004 plagiarised an article from The Nation's Saturday Magazine, Kenya (The Standard, 2004-02-08). Headlined; 'Learn the Very Simple Art of Charming Ladies' the article was authored by The Saturday Magazine's columnist, Cathrine Awuor.

Kachere's case is an example of premeditated plagiarism in the sense that she tempered around with the phrases and names to suit her Zimbabwean context. Where Awuor wrote: 'I have seen friend of mine fall for the line "you look familiar, were in the same high school"; she was in a girl's only school but he got her talking'; Kachere had 'I once fell for the line, "you look familiar", "were we in the same high school", the guy got me talking and the result got me a two year old affair.'

In yet another part, Awuor wrote; 'Today's article is for the man whose idea of dinner is Kenchic takes away...' and Kachere had 'Today's article is for the man whose idea dinner is Cresta 
Mbare...' (The Standard, 2004-02-08). This kind of plagiarism suggests laziness on the part of the writer. Availability of the article on the Internet could also have tempted her to 'copy and paste' as a way of beating her deadline. She also most probably took comfort in the cloak of anonymity that the Internet provides.

Another Zimpapers journalist, a senior sub-editor of The Herald, Tim Chigodo also plagiarised a story from the Daily News of 15 January 2003 and sold it to the African Church Information Service of Nairobi, Kenya (Chari, 2008:56). The story, headlined 'Hunger gnaws as villagers wait for maize that never comes', had been jointly written by the Daily News reporters, Precious Shumba and Ntungamili Nkomo. He copied it verbatim. (The Daily News, 2003-02-28:1-2). Chigodo admitted plagiarising the story and remarked: 'I sometimes correspond for the publication. I think it must have been a mistake. They should have accredited the story to the Daily News but I don't know what happened' (The Daily News, ibid).

The perception that the Internet makes it difficult to trace plagiarism could have motivated these journalists to plagiarise other people's articles and present them as their own.

Courtesy of the Internet, journalists now find themselves amidst a deluge of information. This gives them a false sense of comfort associated with the anonymity of the Internet. The avalanche of information makes it impossible for gatekeepers to monitor subordinates. In some cases, plagiarism becomes more sophisticated so that even the most alert editor would not know who was plagiarising what. It is common to see an article in a newspaper consisting of large chunks of quotes which are not attributed to any source. It is also a common practice in Zimbabwe for journalists to use copy from foreign news agencies such as Reuters, AFP, AP and Irin without proper acknowledgement. Where acknowledgement is given, there is a double by-line, one for the reporter and the other representing the name of the news agency from which the story originated. Proper acknowledgement is never given and closer scrutiny might reveal that half of the story has been copied word for word.

It is not easy to determine how serious the problem of plagiarism is because most of the cases are never reported and also because of the secrecy in which it is practised. There is also the problem of complicity among offenders since journalism is a profession which thrives on solidarity and collegiality. There is a tendency among journalists to protect each other through silence. (anonymous interview: 2008-03-14). The few cases highlighted above, however, show that the problem of plagiarism could be more serious than the public realises.

\section{Vendetta journalism}

The Internet in Zimbabwe has exacerbated what Francis Kasoma refers to as 'vendetta journalism'. Kasoma defines this as 'journalism of hatred, revenge and dislike against people in the news' (Kasoma, 1996:99). Among other things, vendetta journalism employs the following techniques:

- Abusive language against sources 
- Not approaching sources for a comment in a story that criminalises them

- Selective use of facts that paint a bad picture of the source

- Use of sarcasm in reporting stories that the journalists hate (Kasoma, 1996:99-100)

In vendetta journalism, news sources are personally targeted and scandalised even on flimsy grounds. Privacy of individuals is routinely invaded and any means available is justified to get a story. Vendetta journalism is unethical because it violates the core tenets of the journalism profession such as objectivity, balance, fairness and impartiality. Journalism becomes an end in itself rather than a means to an end. Vendetta journalism is a true case of the pen being mightier than the sword.

The emergency of online publications and websites such as ZimOnline, NewZimbabwe.com, The Zimbabwe Times and others has fundamentally transformed journalistic practices in the country. The new technology has rendered stringent media laws such as the Access to Information and Protection of Privacy Act (2001) and the Broadcasting Services Act (2001) null and void resulting in journalists having free reign. Online publications now enjoy 'unfettered liberty' to publish what they want and how they want. After the closure of the Daily News in September 2003, the majority of the journalists went into the Diaspora.

Displaced journalists harbour a grudge with the ruling Zanu (PF) government, particularly key government figures such as President Mugabe, former Minister of Information and Publicity in the President's Office, Jonathan Moyo, Permanent Secretary for Information and Publicity and Presidential Spokesperson, George Charamba, Media and Information Commission Executive Chairman, Tafatona Mahoso and others.

Mahoso has been called 'a media hangman', Moyo was branded a 'nutty Professor', 'Goebels', 'Rasputin', etc and Mugabe has been called 'Hitler', 'Devil' and 'Black Mamba'.

Online publications and websites find it difficult to disguise their hatred for these personages at the cost of their own professional credibility. Although they have done a great job of providing alternative voices within a political environment their aggressive approach has the potential to alienate certain readers who prefer the Aristotelian 'golden mean' or moderation rather than extremism.

Because of the vendetta they harbour against the Zanu (PF) government for 'closing' their newspapers these websites often resort to unethical and unorthodox means of extracting stories that depict the ruling party and government in a bad light. They have, for instance, on numerous occasions reported on the alleged failing health of President Mugabe without sufficient proof. Writing in the Telegraph blogs (in an articled headlined 'Mugabe health rumours') Peta Thornycroft (2006) comments:

"The rumour comes around every year, and usually begins in neighbouring South Africa. This time people phoning from outside Zimbabwe to check on President Mugabe's health, 
said reports that he had died, and caused the South African currency, the Rand to crash to its lowest level in a couple of years. Mugabe, 82, was, so the rumour went, seriously ill. He was last seen on state television in southern Zimbabwe. He looked ok".

TheZimbabweTimes.com published a news article in May 2008 claiming that President Mugabe's health was failing. The writer, editor Geoff Nyarota (also founding editor in 1999), claimed that a picture of President Mugabe taken at an election rally had portrayed the poor health of President Mugabe due to swelling ankles and feet. Nyarota wrote extensively speculating on the causes of feet swelling in order to prove his point that Mugabe was not fit for public office wrote

'My research into the swelling of the feet was fruitful. It revealed that "systematic diseases and conditions are associated with foot and ankle swelling and are characterised by fluid retention or less commonly, by an increase in the thickness of the skin. Diseases of the joins, such as arthritis, can also affect the joints of the ankle and foot, leading to swelling of the involved areas", (Nyarota, 2007).

The article was speculative in its material details dwelling on writer's desires, wishes and supposition thus making it ethically contestable. Although a head of state's state of health is a legitimate concern for every citizen the problem is that speculation may lead to unnecessary alarm and despondency. Any speculative information disempowers rather than empowers. Speculation leads to loss of credibility.

New Zimbabwe.com (2008-05-28) published a speculative article on Mugabe's health. The article created the impression that President Mugabe had lost his sight. The article was based on remarks made by Minister of Information and Publicity, Sikhanyiso Ndlovu, at a meeting held with state media newspapers. Ndlovu is reported to have told the editors that President Mugabe was complaining that the font of the state-owned newspapers was too small ('like ants') and New Zimbabwe.com insinuated that this meant that President Mugabe had lost his vision. The publication wrote: 'Mugabe's state of health is a closely guarded secret, but the disclosure by Ndlovu has given a hint that the 84 year-old's health may be failing.'

While the efforts of these websites in enlarging the democratic public sphere cannot all be ignored, their adversarial and vendetta-like approach has tended to undermine their credibility. The speculative stories that dwell on personalities and not on issues appear to be motivated by the personal whims of the journalists and in some instances, the desire to tickle their readership.

A good number of them are meant to settle scores with enemies or perceived enemies and sometimes hit below the belt. A case in point is a story published by New Zimbabwe.com (2006) where the website alleged Permanent Secretary for Information and Publicity and Mugabe's Spokesperson George Charamba had infected his wife with HIV. Charamba was alleged to have nearly killed his wife in a scuffle after his wife accused him with HIV: 'New Zimbabwe.com has obtained irrefutable information that the savage assault was prompted [by] Rudo Charamba's accusations that Mugabe's wordsmith had infected her with the killer virus that causes AIDS.' 
The article published the details of the fight between the two also chronicling Charamba's 'dirty past'. Although the general approach in journalistic practice is that public figures do not have an absolute right to privacy by virtue of their public stature, in publishing the HIV status of a person without his or her consent is stepping outside the limits of ethical journalism. Disclosing someone's medical records or condition is a morally questionable practice in even the most liberal of societies. Besides there is the problem of promoting stigma about HIV and AIDS at a time when the whole world, Zimbabwe included, is deploying the media in social marketing programming to ameliorate stigmatisation of people living with HIV/AIDS.

This shows that Internet-based publications are using the advantage of operating outside the jurisdiction of the law to wage war against their adversaries. They can afford to defame, impugn, and malign people in the full knowledge libel laws and stringent media laws such as Access to Information and Protection of Privacy Act (which imposes stiff penalties for offences such as the invasion of privacy) and the Broadcasting Services Act are of no consequence since they operate in cyberspace.

Sometimes this unfettered freedom has tended to undermine the same values that they seek to promote - democracy and the right to information. This liberty without responsibility runs the risk of putting this honourable profession into disrepute.

Kasoma (1996:101): argues that:

the harm that unfounded accusations against those in government can do to society and individuals who constitute it can be devastating. Even Africa's dirty politicians, as most of them are, deserve justice and fair play from the media and should not be accused, tried and sentenced by the press of wrongs they have not committed.

By attacking people willy-nilly and seeking to 'destroy' their enemies through the pen, these publications will not have enough time and space to discuss 'bread and butter' issues that concern the people of Zimbabwe.

While they are giving people an alternative source of news about the happenings in Zimbabwe, they must remain true to the ethics of the profession. That is particularly important if they want to convince the people that the reason they have remained in journalism after the closure of their newspapers is their commitment to serving the people which is to educate, entertain and inform the citizens rather than to promote their own selfish interests and to boost their egos.

It is worth noting that although vendetta journalism has escalated to dizzy heights in cyberspace, it is not unique to online publications alone. The mainstream media are equally culpable and have been practising it for a long time.

A case in point is the publication of former Roman Catholic Archbishop of Bulawayo, and strong government critique, Pius Ncube's pictures having sexual intercourse with a married woman in the state media in July 2007. The pictures reported to have been taken by a secret camera hidden 
in Ncube's room. Ncube was facing a Z\$20 billion adultery suit in a Bulawayo court. The case was extensively covered in the State-owned Zimbabwe Broadcasting Cooperation (ZBC TV), state-owned dailies, The Chronicle and The Herald. Of particular concern was the screening of photographs of alleged sexual encounter, particularly on a public service television during prime time. What exacerbates the ethical culpability of the state media outlets is that the pictures were downloaded by other publications and put on the internet and shown all over the world before the case had been completed through legal process (Raath, 2007; Rekayi, 2007).

The insensitivity displayed by the state media towards their audience shows that the media are more prepared to cast caution to the wind in order to settle scores with perceived or real enemies. Respect for moral and ethical standards is now being sacrificed on the altar of political and commercial expedience.

\section{Anonymous sources}

There is a tendency by the Zimbabwean mainstream and online media to use unidentified sources even in stories that are not so controversial. One would not be able to read and finish a newspaper without coming across a story that says 'according to highly placed sources'; 'authoritative sources who refused to be named for fear of victimisation' or 'sources who requested anonymity'. Although there are situations where sources deserve legitimate protection there is a danger that too many 'anonymous' sources may result in the reader being sceptical. It would seem that the increasing use of anonymous sources in both mainstream and online publications is a result largely of the following reasons:

- Pressure of deadlines occasioned by the fast pace of journalism in the digital age. Sometimes journalists hardly have enough time to approach sources due to deadlines. This is particularly the case with daily publications and online publications

- Lazy journalism. This results from lack of motivation, lack of adequate training and availability of ready-made news copy on the ]Internet and foreign news agencies

- Pure fabrication. Sometimes stories are fabricated completely and as a result they cannot be traced to any source

- Lack of access to news sources. Political polarisation in the country makes it difficult for journalists to get comments from news sources because of hostility. Government officials and ruling Zanu (PF) politicians often refuse to be interviewed by private media and online publication journalists while government owned media journalists also have a hard time trying to get comment from opposition politicians who also view the sate owned media as an adversary. It is common for politicians or government officials to switch off their cell phones once they recognise that the caller from the other end of the line is from an 'enemy side'. Faced with deadlines and with no other alternative, journalists are forced to speculate and in some cases simulate interviews. When the alleged source denies ever talking to the writer of the story the reading public becomes more suspicious and may lose confidence when they get to know about the faked interviews. Fear of losing 
credibility has made editors reluctant to publish prominent retractions as is required by law.

It is worth noting that online publications are more culpable in this respect due to lack of correspondents on the ground. Even where they have, the person cannot cover every part of the country. They may have to depend on colleagues, rumours, mainstream newspapers or other informal sources, thus raising more serious ethical questions relating to speculation and plagiarism. Matusitz (2007:2 ) refers to 'unscrupulous copycat behaviour that stems from journalistic laziness' which results in identical stories, using same sources, each one churning out the same words, asking the same questions and ending up with the same article.' Although Matusitz was referring to 'pack journalism', the same is true with all other journalists in the age of the Internet. It is even more applicable to online journalism.

\section{Implications and the future}

There is no doubt that the Internet has revolutionarised journalism in Zimbabwe in terms of providing alternative platforms for news and information and for challenging Zanu (PF) hegemony. However, uncritical sympathisers of the country's opposition have tended to overlook the ethical conduct of these media while celebrating their ability to present an alternative voice.

Although the performance of both the mainstream and online media have eluded academic interrogation due to, among other factors, the political polarisation in the country, the journalists are not completely unaware of their shortcomings.

A few cases are worth citing in order to drive the point home.

First, we have the case of British born and turned Zimbabwean journalist Peta Thornycroft who has worked as a journalist in Zimbabwe since 2001. Thornycroft sheds more light on the ethical pitfalls of both online and mainstream media in reporting the Zimbabwe story. Thornycroft (SW Radio, 2007-11-06) voices her contempt for some of the online newspapers published outside the country when she says:

So I have been very disappointed with lots of external media. ZimDaily - I suppose now [I] view ZimDaily as an essential part of my life covering Zimbabwe because it makes me laugh...I have shrieked with laughter often times at some of the stories and the way they have been hounding the Chefs' children - who are in Universities and colleges overseas and some of the comments that followed on their website made me scream with laughter. So I do not take it seriously as a news outlet, it is kind of silent.

Thornycroft (SW Radio, 2007-11-06) underlines the Zimbabwean media's loss of credibility when she says journalists reporting for the international media have been ignoring online publications because their stories are not substantiated. 
There are far too many stories on Zimbabwe that go without named sources. And so one gets this extraordinary exaggeration. And The Zimbabwean newspaper which is mostly run by very experienced journalists, who have a lot of advantages in their lives, I am quite shocked really at the standard of some of the reporting that goes out on The Zimbabwean - that $\mathrm{i}[\mathrm{t}]$ just does not fill the basics on the hard newspapers. Their stories do not have the basic requirements needed for a news story and it is the type of paper which really look very nice and useful to people living in the United Kingdom - I have not found that some of the sensational front page stories stood up to any kind of professional scrutiny. And I think that's a pity.

That, coming from a fellow journalist, helps send home the point that The Zimbabwean is suffering from a serious credibility crisis.

As Maimbodei (2007:9) would argue, these ethical shortcomings 'raise questions on the efficacy of the media as pillars and the mainstay of democratic principles and on the media as a link connecting people across various issues.'

Credibility is an important index of media efficacy in democracy and without which it would be difficult to say the media have any role to play in a society.

Studies have shown that the most important dimensions of media credibility are believability, accuracy, unbiased reporting and depth and completeness (Mingxin, 2006:41). West (1994) cited by Mingxin (2006:37) defines media credibility as 'the qualities of information source which cause what it says to be believed beyond any proof of its contentions.' Zimbabwean mainstream and online media need to improve on their credibility levels if they are to make a meaningful contribution to democracy. As has been argued by other scholars, these media need to appreciate that the cardinal tenets of journalism ethics such as 'honesty, accuracy and fairness do not go out of fashion because technology changed' (News Hour, 1999, cited by Arant, 2000).

This paper recommends an ethical approach based on traditional ethical values of journalism as a way of preserving societal moral values. There is no inherent contradiction between technological progress and the preservation of moral values. While media pluralism is one positive aspect of technological progress pluralism must catalyse public debate without undermining moral imperatives of the community. The writer concurs with Christians et al (1993:px ) who argue that: 'the concept of media responsibility recognises that individuals live in community, that they rely on others for their very physical and social life.'

While there is a need to adapt to new realities the new media should not discard traditional values and old wisdom which has guided the profession for centuries. The importance of sticking to professional ethical codes of conduct to guide the new crop of journalists should be stressed, rather than leaving the new crop of journalists to their own devices. Traditional media need to continuously update their codes to ensure that they move with the times while at the same time maintaining the core values of professional journalism. In-house courses can also act as a 
constant reminder on the importance of observing professional ethics and also help journalists navigate ethical challenges occasioned by the ever changing technological environment.

\section{Conclusion}

This paper discussed journalistic practices in Zimbabwe in the context of the Internet age. The paper acknowledges the positive opportunities unlocked by the Internet for the media in the country but raises concerns over the myriad ethical challenges associated with the technology which tends to undermine the efficacy of the mass media in deepening democratic cultures in Zimbabwe.

It has been noted that the Internet has directly and indirectly promoted unethical journalistic practices such as plagiarism, factual inaccuracies, activist journalism or vendetta journalism and invasion of privacy which all tend to undermine the credibility of the media in Zimbabwe.

The paper notes that although both the mainstream and online media are not immune from the ethical pitfalls associated with the Internet, online publications that directly operate from this platform suffer more from the risk of violating ethics of the profession than the traditional media. It was also demonstrated that the presence of these ethical challenges compromises the quality of information disseminated by these media and consequently their ability to act as credible sources of information for empowering citizens.

Insights gleaned from this study are instructive in so far as they exhort the journalistic fraternity to think critically and reflect on the substance of their work in the context of a technological revolution that has its own contradictions. There is a need for the media in the country to reexamine their current newsgathering practices. The paper calls for an approach which is rooted in the traditional values of journalism where objectivity, balance, impartiality, fairness, truthtelling, integrity and respect for others are valued.

Only ethical and professional media are capable of engendering genuine liberation and empowerment through the dissemination of credible and quality information that can nourish the human intelect.

To that extent both the mainstream and online media should craft relevant ethical codes to guide their cadres - some of whom seem to be flying blindly, thereby bringing the honourable profession into disrepute.

\section{Author details}

Tendai Chari is a Media Studies Lecturer in the Department of Communication and Applied Language Studies at the University of Venda, Limpopo Province, South Africa. His research interests are Media Ethics, Media and Democracy, Political Communication and Media Representation.

\section{Contact details}

Email: tjcari@yahoo.co.uk 


\section{References}

Alden C. 2004. 'For most Africans Internet Access is little more than a pipe dream'. Online Journalism Review. 2004-03-03, Accessed: 2008-03-05, http://www.ojr.org/ojr/workplace

Andres, L., Cuberes, D., Diouf, M. A. \& Serebrisky T. 2008. Diffusion of Internet: a cross country analysis, MPRA Paper, No. 8433. 2008-03-15 Accessed: 2008-05-20 http://mpra.ub.unmuenchen.dy/8433

Anim E. 2007. Internet use among Nigerian journalists. In: Lwati: Journal of Contemporary Research. Vol 14:348-361.

Arant D. 2000. Online media ethics: a survey of US daily newspaper editors. Paper presented at the Association for Education in Journalism and Mass Communication Convention, Phoenix, 2000-08. http://www.factstaff.elon.edu.anders/onlinesurvey.html Accessed 2008-05-09

Belsey A. \& Chadwick, R. 1992. Ethical issues in journalism and the media. London: Routledge.

Berkman R.I. and Shumway, C. 2003. Digital dilemmas: ethical issues for online media professionals. London: Blackwell Publishing.

Brislin, T. 2004. Empowerment as a universal ethic in globalism. In: Journal of Mass Media Ethics. 19(2):130-137.

Chari, T. 2006. Broadcasting in Zimbabwe. In: Mixed signals: the state of broadcasting in southern Africa. Zambia: Panos Institute.

Chari, T. 2007. Rethinking ethical issues in African media. In: African Identities, 5(1):39-60.

Chinhamo, R. Ngugi Wa Mirii dies in a car crash. The Zimbabwemetro. 2008-05-04.

Chirovamavi, M. (Interview 2009-05-06)

Chisenga, J. 1999. Global information infrastructure and the question of African Continent. Paper Presented at The $65^{\text {th }}$ IFLA Council and General Conference, Bangok, Thailand, 1999-0820-28.

Christians, G. C., Rotzoll, K. B. and Fackler, M. 1983. Media ethics: cases for moral reasoning. New York \& London: Longman.

Christians, G. C. 2004. Ubuntu and communitarian media ethics. In: Equid Novi: African Journalism Studies. 25 (2):235-256.

Christians, G. C., Ferré, J. P. \& Frackler, P. M. 1993. Good news: social ethics and the press. Oxford: Oxford University Press. 
Christians, G.C. 1989. Ethical theory in a global setting. In: Cooper, T., Clifford, G. C., Plude, F.F. and White, A. R. (Eds): Communication ethics and global change. New York: White Plains.

Cooper, W.T. 1989. Global universals: in search of common ground. In: Cooper, T., Clifford, G. C., Plude, F.F. and White, A. R. (Eds): Communication ethics and global change. New York: White Plains.

Cooper, W.T. 1989. Introduction. In: Cooper, T., Clifford, G. C., Plude, F.F. and White, A. R. (Eds): Communication ethics and global change. New York: White Plains.

DIFD. 2008. Country Profiles-Zimbabwe. Accessed: 2008-05-25, http://www.difd.gov.uk/country/profiles/Zimbabwe

Feltoe, G. 2002. A guide to press law. Harare: Legal Resources Foundation.

Fink, A. 2003. The survey toolkit. London: Sage Publications.

Foreign and Commonwealth Office. 2008. Country Profiles-Zimbabwe. Accessed: 2008-03-03 http://www.fco.gov.uk/en/about-the fco/country-profile/Zimbabwe.

Gall, M.D., Borg, W.R. \& Gall, J.P. 1996. Educational research: an introduction. New York: Longman.

Genevieve, R. 2005. Publish and be damned. The Independent (UK): 2005-02-09. Accessed: 2008-05-24: http://www.findarticles.com/p/articles

Gordon, D. A. \& Kittros, J. M. 1999. Controversies in Media Ethics. London: Longman.

Independent Election Results Centre: http://www.zimelectionresults.com

International Telecommunication Union. 2005. World Information Society, Geneva 2003, \& Tunisia 2005. Accessed:2008-03-15 http://www.itu.int/wiss/tunis/newsroom/stats.

Internetworldstats.com. 2008. Internet use in Africa. Accessed: 2008-03-15 http://www.internetworldstats.com

Internretworldstats.com. 2008. Internet use in Zimbabwe. Accessed: 2008-03-15 http://www.internetworldstats.com

Jensen, M. 2000a. Making the connection: Africa and the Internet. In: Current History, May 2000 .

Jensen, M. 2000b. African Internet Status, November 2000. Accessed: 2008-03-15 http://www.banners.noticiasdor.com/termometro. 
Kasoma, F. 1996. The foundations of African ethics (Afriethics) and the professional practice of journalism: the case for society centred media morality. In: African Media Review, 10 (3).

Kenny, C. \& Hawkins, R. 2000. Economic Internet toolkit for African policymakers: an African Internet forum. UNECA and InfoDev Project. Accessed: 2008-03-03

http://www.infodev.org/project/finafcom.htm

Kubatana.com http://www.kubatana.net.

Lasica, J.D. 1997. Preserving old ethics in a new medium. American Journalism Review, December 1997. Accessed: 2008-03-03: http://www.ajr.org/articles.asp

Lucas, L. 2005. Botswana. In: Berger, G. (Ed): Doing digital journalism: how southern African newsgatherers are using ICT: Grahamstown: Rhodes University.

Lush, D. \& Kupe, T. 2005. Crisis? What crisis? In: Report on International Conference on Media Support Strategies for Zimbabwe, International Media Support (IMS), The Netherlands Institute for Southern Africa, (NIZA), Media Institute for Southern Africa, (MISA), Open Society Institute. 2005-11-30. Accessed: 2008-03-03, http://www.i-m-s.dk/media/pdf/Zimbabwe.

Mabweazara, H. (2005) Zimbabwe. In: Berger, G. (Ed): Doing digital journalism: how southern African newsgatherers are using ICT: Grahamstown: Rhodes University.

Madon, S. 2000. The Internet and socio-economic development: exploring the interaction in information technology and people. In: MCB University Press: 13(2):85-101.

Maimbodei, S. 2008. Thorncroft indicts international media. The Herald, 2008-01-24.

Martin, B. 1984. Plagiarism and responsibility. In: Journal of Tertiary Educational Administration, 6(2):83-90.

McDonald, B. \& Petheram, M. 1998. Media effects. London: Mansell.

Merrill, J. 1999. Foundations for media ethics. In: Gordon, D. A. \& Kittross, J. M. (Eds): Controversies in media ethics, London: Longman.

Mingxin, Z. 2006. The present situation and analysis of mass media use and credibility in countryside of mid-China: the case of Hubei Province in China. In: Media Research, 2(4):37-47.

MMPZ (2002). Media under siege: report on media coverage of the 2002 presidential and mayoral elections in Zimbabwe, Media Monitoring Project of Zimbabwe, Harare.

Moyo, D. 2007. Alternative media, diasporas and the mediation of the Zimbabwean crisis. In: Ecquid Novi African Journalism Studies, 28(1\&2): 81-105. 
Mukwazhi, T. 2007. Police beatings - what really happened, top journalist speaks. Kubatana, 2007-03-18. Accessed: 2008-05-28: http://www.kubatana.net.

Musa, D. (1996). The sleeping dog cannot bark: media and mass disempowerment of civil society in Africa. In: Africa Media Review, 10(3).

New Zimbabwe.com. Mugabe's vision poor, he can't read newspapers, 2008-05-28. Accessed: 2008-06-07 http://www.newzimbabwe.com/pages/mugabe

Ncube, J. 2007. Do lies really outsell the truth? NewZimbabwe.com. 2007-07-27, http://www.newzimbabwe.com/pages/ijaz33 Accessed: 2008-05-24.

Nordenstreng, K. 1989. Professional ethics in transition. In: Cooper, T., Clifford, G. C., Plude, F.F. and White A. R. (Ed): Communication Ethics and Global Change. New York: White Plains.

Nyakunu, N. 2005. The working environment in Zimbabwe. In: Report on International Conference on Media Support Stategies for Zimbabwe, International Media Support (IMS), The Netherlands Institute for Southern Africa, (NIZA), Media Institute for Southern Africa, (MISA), Open Society Institute, 2005-11-30. Accessed:2008-03-23:http://www.i-ms.dk/media/pdf/Zimbabwe.

Nyamnjoh, F. B. 2005. African media: democracy and the politics of belonging. Pretoria: Unisa Press.

Nyarota, G. 2008. Charamba now targets online publications. The Zimbabwe Times.com, 200802-04. Accessed: http://www.zimbabwe.journalists.com/authors, Accessed: 2008-05-15

Nyarota, G. 2008. Poor health now Mugabe's worst enemy. TheZimbabwetimes.com, 2008-0531., Accessed: 2008-06-20 http://www.thezimbabwetimes.com,

Osborn, B. 2001. Ethics and credibility in online journalism. JOUR 6702, Current Issues in Journalism.

Ott, D. \& Rosser, M. 2000. The electronic republic: the role of the Internet in promoting democracy in Africa. Democratisation, 7(1):137-158.

Raath, J. 2007. Did Mugabe regime fake pictures of the Archbishop 'Caught in Flagrante'? 2007-07-18, Accessed: 2008-05-15, http://www.timesonline.co.uk/to/news/world/africa

Rao, S. \& Wasserman, H. 2007. Global media ethics revisited: a post-colonial critique. In: Global Media and Communication, 29(3). Accessed: 2008-02-28 http://gmc.sagepub.com 
Rekayi, D. 2007. Zimbabwe: Ncube coverage 'an affront to ethical journalism'. MISA. Zimbabwejournalists.com. Accessed: 2008-02-24 http://www.africompath.com, 30/05/2008

Roycroft, T. \& Anantho, S. 2003. Internet subscription in Africa: policy for a digital divide. In: Telecommunication Policy, 27(1\&2):61-74

Saunders, R. 1991. Information in the interregnum: the state and civil society in the struggle for hegemony in Zimbabwe, 1980-1990. Unpublished PhD Thesis, University of Carleton, Canada.

SW Radio Transcript. 2007. Hot seat transcript: foreign correspondent Peta Thornycroft on media in Zimbabwe. 2007-11-06. Accessed: 2008-02-20 http://swradioafrica.com/pages/hotseat

The Daily News. Woman's body not found. 2002-04-27:1.

The Daily News. Herald staffer steals story from Daily News. 2003-02-28:1-2.

The Standard. Another Zimpapers editor in trouble for plagiarism. 2004-02-08.

Thornycroft, Peta 2006. Mugabe health rumours. The Telegraph. 2006-06-22. Accessed: 200803-22 http://bolgs.telegraph.co.uk/foreign/petathorncroft/june06/health+rumours.htm

The Zimbabwemetro. Ngugi Wa Mirii dies in a car crush. 2008-05-02. Accessed: 2008-05-10 http:/Zimbabwemetro.com

Waldahl, R. 2004. Politics and persuasion: media coverage of Zimbabwe's 2000 election. Harare: Weaver Press.

Watson, J. \& Hill, A. 1984. A dictionary of communication and media studies. London: Edward Arnold. 